\title{
Negative Strategies and World Disruption in Postapocalyptic Fiction
}

\author{
Marco Caracciolo
}

Ghent University

\section{$\underline{\text { marco.caracciolo@ugent.be }}$}

Published in Style 52 no. 3, pp. 222-241, please quote from published version

\section{Abstract}

This essay engages with the challenges of narrating catastrophe in so-called postapocalyptic fiction, and more specifically in three contemporary novels that bring formal and stylistic sophistication to the genre: Cormac McCarthy's The Road (2006), Colson Whitehead's Zone One (2011), and Emily St. John Mandel's Station Eleven (2014). I claim that these novels are able to evoke a strong sense of the disrupted temporality of catastrophe through what I call "negative strategies." These are formal devices that leverage the underlying psychological structure of negation in order to confront readers with the absence of the preapocalyptic world. My textual analyses are part of a broader attempt to understand how the imbrication of human and nonhuman realities (as revealed, in my corpus, by catastrophe) impacts narrative not just in thematic but in formal terms.

\section{Keywords}

Cognitive literary studies, nonhuman turn, mental imagery, narrative space, contemporary fiction

\section{Introduction}

Literary scholars love catastrophe. From Maurice Blanchot's seminal Writing of the Disaster to recent work in ecocriticism (Rigby, Dancing with Disaster), catastrophe and disaster have been discussed extensively in literary scholarship. But the formal challenges raised by catastrophe have not been investigated as thoroughly or systematically from a narratological perspective. As the field of narratology moves "beyond the human" (Herman, "Narratology") and confronts the environmental 
imagination (James), a key question concerns how the representation of the large scale and complex causality involved in catastrophic events can impact narrative practices. When seen through the lens of recent discussions on the "nonhuman" (Grusin), catastrophe reveals the fundamental interrelation between human societies and processes whose spatio-temporal scale transcends that of human perception (such as rising sea levels, the ecosystem, etc.). How can narrative overcome its "anthropomorphic bias" - in Monika Fludernik's (13) term - and integrate the nonhuman realities of biology, geology, and the climate into its formal workings?

This article posits that catastrophe is a productive concept to leverage in addressing these issues. Catastrophe consists, essentially, in an event that causes a radical instance of what David Herman (Basic Elements 133-136) calls "world disruption." For Herman, world disruption and narrative worldmaking are two sides of the same coin: narrative worldmaking is triggered by events that destabilize the status quo of a world, and are therefore surprising and highly tellable. Catastrophe owes its inherent tellability to the profound destabilization it brings about. My focus in the following pages will be postapocalyptic fiction, a genre that builds catastrophic destabilization into the very structure of a storyworld: by definition, postapocalyptic fiction implies and foregrounds a catastrophic rupture between a preapocalyptic and a postapocalyptic state of the storyworld. The former is typically aligned with present-day reality, the latter is a dystopian world in which few survivors face extremely harsh conditions and new (usually, more primitive) social structures. At the same time, the postapocalyptic scenario reveals something about the pre-world: as James Berger writes in After the End, the "apocalyptic event, in order to be properly apocalyptic, must in its destructive moment clarify and illuminate the true nature of what has been brought to an end" (5). More specifically, I will be arguing that postapocalyptic fiction holds considerable potential to reveal the fundamental interdependency between human societies and the biological, geological, or climatological phenomena that led to the apocalyptic event. Thus, the genre raises narratological questions that are both distinctive and indicative of the broader stakes involved in capturing the nonhuman in narrative form. 
To begin with, the storyworlds constructed by postapocalyptic fiction are closely related to what Lubomír Doležel calls "dyadic worlds" (128-129)—which are split into two domains characterized by distinct and often diametrically opposed conditions. But whereas Doležel conceives of these domains as fundamentally spatial (they are distinct parts or dimensions of a storyworld, as in Franz Kafka's The Castle, one of Doležel's examples), postapocalyptic fiction is dyadic in its temporal extension. Usually, however, postapocalyptic fiction is set in the post-world and only implies the pre-world as a backdrop to the plot. The central narratological challenge raised by the genre is, then, how this act of narrative implication operates, how a story can evoke a preapocalyptic state via the outcome of a catastrophe.

This challenge is certainly not new, given the long and varied history of postapocalyptic fiction. Mary Shelley's The Last Man (1826) is usually hailed as the first novel in the genre, which soon became a staple of science fiction. In the second half of the $20^{\text {th }}$ century, the postapocalyptic imagination was fueled by Cold War anxieties of nuclear annihilation (see Kohlmann) and started to engage with human-induced natural disasters: J. G. Ballard's The Drowned World (1962), for instance, is considered a particularly influential prefiguration of contemporary novels dealing with climate change. Nor is postapocalyptic fiction limited to the novel: today, the genre has a significant presence in comic books and TV (The Walking Dead), video games (the Fallout franchise), and film (the Mad Max series). The novels I will be dealing with in this article build on the catastrophic imaginary created by these widespread cultural representations, even as they approach postapocalyptic motifs with distinctive sophistication and self-consciousness. They are Cormac McCarthy's The Road (2006), Colson Whitehead's Zone One (2011), and Emily St. John Mandel's Station Eleven (2014).

These novels are certainly not unique in their "literary" take on the postapocalyptic genre, but they are representative of how the postapocalyptic set-up, along with the diverse repertoire of popular representations of the apocalypse, lend themselves to a stylistically sophisticated approach. This 
increased formal complexity is made evident by the novels' handling of narrative temporality. While, as we have seen, any narrative in this genre presupposes a temporal rupture between a pre- and a post-world, my case studies probe this divide in formal terms, as a means of engaging with the psychological consequences of catastrophe: the emphasis falls not on apocalypse as a plot device, but on its power to disrupt the protagonists' experience of reality-and particularly their sense of a sharp demarcation between human societies and nonhuman things and processes. This conceptual destabilization is an effect of what I call "negative strategies": the post-world emerges as the narrative negates (i.e., subtracts or pares down) some of the salient characteristics of the preworld-features with which readers are familiar through their everyday reality. Thus, famine negates the availability of food and other resources, the postapocalyptic wasteland negates the organized urban environments of the pre- period, widespread violence contradicts the rule of law, and so on. This may sound like a schematic process, but it is central to the genre of postapocalyptic fiction and-as I argue in the next section-it leverages important structural feature of readers' imagination. In my case studies, negative strategies are deployed in a particularly effective and selfconscious way, in order to foreground psychological rupture and maximize its imaginative impact on readers. In my approach I will thus combine formal analysis with insights drawn from "secondgeneration" cognitive approaches to narrative, which highlight the reader's share in making sense of narrative affectively and imaginatively (see Kukkonen and Caracciolo).

\section{Negation in Language and Mental Imagery}

Narrative theory has so far addressed negation in the form of "denarration," in Brian Richardson's term: Richardson defines it "a kind of narrative negation in which a narrator denies significant aspects of her narrative that had earlier been presented as given" (168). The kind of narrative negation that this article explores - and that, I posit, plays a key role in postapocalyptic fictionworks differently from denarration: it does not revoke previous narrative information but conveys the hiatus between two temporal frames, both of which are "presented as given" - but at different times in the storyworld's chronology. 
Consider the so-called Kanizsa triangle, from the name of the Italian psychologist who first described this optical illusion in the 1950s (see Kanizsa and Figure 1 below). We see a triangle brighter than the background, even though we know-or even after we've been told-that, strictly speaking, there is no triangle, because the background and the area at the center of the figure are exactly the same color. Technically, this is known as an "illusory contour." Central to the experience of this figure is the simultaneous, and therefore paradoxical, awareness of something (the triangle) and its absence. Negative strategies in postapocalyptic fiction work in a fundamentally similar way: they conflate the imagination of something and the poignant awareness of its absence. This dynamic leverages some more general features of the psychology of negation, which we can examine along two dimensions. The first is concerned with how people process negation as a linguistic phenomenon; the second turns to negation as an intrinsic feature of mental imagery, including the imagery that arises while reading narrative.

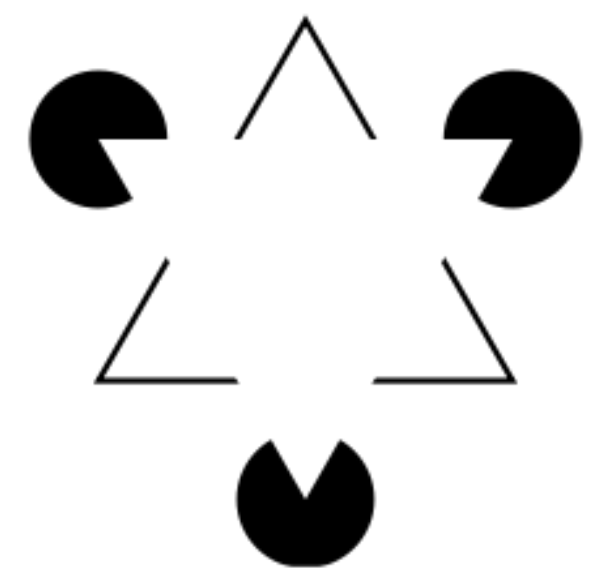

Figure 1 The Kanizsa triangle. Image created by Fibonacci (own work), CC BY-SA 3.0, https://commons. wikimedia.org/w/index. php?curid=1788215.

"The bird is alive" and "the bird is not dead" mean, logically speaking, the same thing. But, in terms of how they are processed psychologically, these statements are quite different. Referencing Laurence Horn's A Natural History of Negation (3), Daniel Gilbert puts this point as follows: “to comprehend a denial (armadillos are not herbivorous), a listener must first comprehend the core 
assertion (armadillos are herbivorous) and then reject it" (113). This means that, when we process a negative statement, we entertain its affirmative counterpart before fully parsing its negative meaning. We do so in an unconscious way, without any awareness that we are considering the affirmative statement. But the repeated use of negation in the novels I will examine below can "fix" the reader's imagination on the realities that are being negated, so that they come into full awareness: for a moment, a statement and its opposite appear to co-exist. These narratives evoke the post-world as a negation of the pre-world-a strategy that, as a matter of fact, affirms the preworld while foregrounding its absence in affectively charged terms. In readers, this gives rise to a sense of double vision comparable to the Kanizsa triangle: mentally entertaining two worlds at the same time serves as a poignant reminder of the material things and social structures that were lost in the catastrophic transition.

This idea can be better understood by taking into account work on the phenomenology of the imagination. When we talk about mental imagery, we usually focus on the substantive contents of our imagery: the things that we experience as part of an imaginative act. Yet phenomenological analysis complicates this commonsensical view of mental imagery significantly. For instance, Evan Thompson writes that we "visualize an object or scene by mentally enacting or entertaining a possible perceptual experience of that object or scene" (138). He adds that mental imagery is different from perception: while in perception we experience objects or scenes as physically present, mental imagery allows us to experience them as absent (Thompson 151). Mental imagery, thus, operates analogously to perception, minus the sense of presence that accompanies perceptual experience. This is, fundamentally, an instance of negation that is part and parcel of the experiential structure of mental imagery. Jean-Paul Sartre raises this point in a passage of The Psychology of Imagination:

The [mental] image also includes an act of belief, or a positional act. This act can assume four forms and no more: it can posit the object as non-existent, or as 
absent, or as existing elsewhere, it can also "neutralize" itself, that is, not posit its object as existing. Two of these acts are negations, the fourth corresponds to a suspension or neutralization of the proposition. The third, which is positive, assumes an implicit negation of the actual and present existence of the object. This positional act-and this is essential-is not superimposed on the image after it has been constituted. The positional act is constitutive of the consciousness of the image. (16)

Not only are imagined objects by definition absent from our immediate surroundings, but we can experience their absence within the act of imagination itself. When this happens, in Sartre's third case, we imagine objects or scenes under erasure: we bring them to life through the imagination but at the same time we negate their presence, precisely as seeing the Kanizsa triangle involves an awareness of the triangle's absence, or as the comprehension of negative statements involves entertaining both their affirmative counterpart and its negation.

This is a structural feature of mental imagery that postapocalyptic fiction can use in particularly effective ways, because of the constitutive absence of the pre-world. Scholars working in cognitive approaches to literature have suggested that the imagery elicited by fiction can be exceptionally vivid (Scarry) and can result in a sense of embodied presence (Kuzmičová): thanks to the stylistic qualities of literary narrative, readers may physically feel part of the storyworld that is being evoked by a text. In narratives of catastrophe, the pre-world haunts readers' imagination of the post-world, increasing its vividness, affective impact, and potential for embodied involvement. At the same time, the core of absence probed by readers' imagination evokes the complexity of catastrophe itself: how catastrophe results from, and reveals, the entanglement of human and nonhuman realities. It is time to exemplify these claims through my case studies. I will begin from Station Eleven, which deploys negative strategies in an exceptionally straightforward way, and then move on to the more indirect uses of negation in The Road and Zone One. 


\section{Enumerating What Is No More: Station Eleven}

The first part of Emily St. John Mandel's Station Eleven is set in present-day Toronto, at a time in which the news of a virus outbreak of unprecedented scale is beginning to emerge. One of the novel's main characters, Jeevan, "was crushed by a sudden certainty that this was it, that this illness . . . was going to be the divide between a before and an after, a line drawn through his life" (20-21; italics in the original). But while this temporal hiatus is only foreshadowed in the first five chapters, chapter six changes gear and presents the reader with what the narrator characterizes as "an incomplete list." This list takes up four pages (the entirety of the chapter) and begins as follows:

No more diving into pools of chlorinated water lit green from below. No more ball games played out under floodlights. No more porch lights with moths fluttering on summer nights. No more trains running under the surface of cities on the dazzling power of the electric third rail. No more cities. No more films, except rarely, except with a generator drowning out half the dialogue, and only then for the first little while until the fuel for the generators ran out, because automobile gas goes stale after two or three years. (31)

The multiplication of negative statements describes, indirectly, how the virus outbreak reshaped the reality of those who survived. This enumeration evokes a postapocalyptic world by subtracting things with which both the novel's readers and the inhabitants of the fictional Toronto of the previous chapters are intimately familiar. Crucially, this negative strategy can create vivid, and hauntingly persistent, mental images, just as the Kanizsa triangle is strongly perceived as present despite our awareness of its absence. This effect depends, in part, on the skillful use of what Scarry (77-88) calls "radiant ignition": many of the sentences in the quoted passage allude to light and light sources, such as the water "lit from below," the "porch lights," or (indirectly) the light of the film projector. References of this kind, Scarry suggests, set the reader's imagination in motion; through the chiaroscuro-like contrast between light and darkness ("the trains running under the surface of 
cities"), they infuse the represented world with dynamic, lifelike qualities. The fact that the passage teems with objects that are both concrete and quotidian, and therefore can be easily visualized by readers, heightens this overall imaginative effect. The three-word sentence about the vanished cities marks an abrupt shift in spatial scale, which serves a strategic purpose: it communicates the scope of these negative statements, how they operate not only on individual objects but on a planetary scale. What the passage conveys, therefore, is deep sense of nostalgia for a world that does not exist anymore, and whose absence is vividly evoked through a series of negative statements.

Not only does the storyworld's temporally dyadic structure inflect the reader's imagination, but it underlies the organization of the narrative as a whole. The novel's multiple storylines straddle the dividing line between the "before" and the "after": chapters 1-5, 13-15, 17, 25-30, 32, 34, 36, 3941, and again 53-54 are set before and in the immediate aftermath of the outbreak, with the other chapters taking place several years afterwards. The protagonist of the latter chapters is Kirsten, a young woman who travels through the wasteland of North America with a company of actors. Kirsten owns a precious relic of the pre-world, a sci-fi comic book titled, like the novel, Station Eleven. This comic book was given to Kirsten by Arthur Leander, a famous actor who died during a Toronto performance of King Lear-a dramatic moment related in the novel's first scene. In parallel, the novel narrates both Kirsten's struggles in the post-world and the events that led to (and surrounded) Arthur's death in the pre-world; several chapters focus on Arthur's first wife, Miranda, the author of the comic book now in Kirsten's possession.

In structural terms, the comic book brings together the plot's strands, so that the progression of the narrative appears to be controlled not by a single character's intentions but by the material circulation of an inanimate object: the comic book connects all the major characters, without them becoming fully aware of one another's lives; only the reader has a complete picture of the comic book's history. The plot is thus "object-oriented" in the sense that it is driven by a material object (see Caracciolo, "Object-Oriented Plotting"). Remarkably, that plotting strategy builds on and 
integrates the thematic significance of the object, its being located at the intersection of pre- and post-worlds, of human lives and the nonhuman event that disrupted them (i.e., the catastrophic virus outbreak). The narrative told in that comic book, which we only glimpse, centers on a lonesome physicist who lives on a space station built in the earth's image, after our planet has been taken over by an alien species. The setting is clearly dystopian and postapocalyptic, and the novel quotes repeatedly the following lines attributed to Dr. Eleven, the physicist: "I stood looking over my damaged home and tried to forget the sweetness of life on Earth" (214). This inability to forget the world before the catastrophe is the feeling that the novel conveys via the negative enumeration of chapter six: that haunting presence-absence of the pre-world, inscribed into the workings of the reader's imagination by the list, is perfectly encapsulated by Dr. Eleven's words.

Moreover, the negative experience of the pre-world echoes many of Kirsten's own statements: "[We] are always looking for the former world, before all the traces of the former world are gone," she reflects (130); later, she adds that "the people who struggle the most with [the postapocalyptic world] are the people who remember the old world clearly" (195). The same nostalgia for a world that is no more is mirrored, at the level of the formal organization of the novel, by the repeated temporal back-and-forths, which follow the vagaries of the comic book, one of those rare "traces of the former world." The negation of familiar objects performed by the enumeration is thus made into a thematic focus and, concurrently, into a principle of formal organization: the juxtaposition of temporal frames in the narrative keeps alive the pre-world in the reader's mind just as linguistic negation foregrounds the absence of what is denied. In this way, the plot captures and models the characters' inability to let go of the preapocalyptic past. Station Eleven thus draws its affective power and distinctly elegiac tone from the way in which the negation of a recognizably contemporary world inflects the whole narrative. 


\section{Negating Color, Negative Space: The Road}

In Cormac McCarthy's The Road-perhaps one of the most influential postapocalyptic novels of the literary variety-an unspecified catastrophe has turned the world into a sparsely populated wasteland. The protagonists are a man and his son, both of them unnamed, who attempt to escape the devastation of what is repeatedly portrayed as a dying world. The storyworld's dyadic temporality is here implemented not via multiple storylines that interweave the pre- and the postworlds, but through passages focusing on the man's dreams, which hark back to his experiences before the disaster. These dream sequences are short inserts, often no longer than a couple of sentences, for instance: "Rich dreams now which he was loathe to wake from. Things no longer known in the world. The cold drove him forth to mend the fire. Memory of her crossing the lawn toward the house in the early morning in a thin rose gown that clung to her breasts" (McCarthy 131). The female character is the man's partner (and the boy's mother), who committed suicide in the aftermath of the disaster: she is among the memories brought back by the dream, one of the few strands still linking the man to the preapocalyptic world. The contrast between the present and the past evoked in the man's dreams is underlined by the fact that the dreams are "so rich in color. How else would death call you? Waking in the cold dawn it all turned to ash instantly. Like certain ancient frescoes entombed for centuries suddenly exposed to the day" (21). As the simile emphasizes, the transition between the dreams' pre-world and the present is marked by a sudden perceptual change: the dreams are in color, the postapocalyptic world only presents shades of gray.

The narrator's insistence on the monochromatic landscape is the main route through which negation operates in the novel: while Station Eleven focuses on the denial of objects, technologies, and practices of the pre-world, The Road embeds that denial into the perceptual features of the landscape that surrounds the protagonists. The world is progressively drained of its familiar chromatic qualities; the novel's beginning announces: "Nights dark beyond darkness and the days more gray each one than what had gone before. Like the onset of some cold glaucoma dimming away the world" (3). Throughout the novel, the wasteland in which the man and his son travel is so 
relentlessly characterized as gray and ashen that few readers will miss its colorlessness, as attested by several commentators: "The book is written in language almost like watching black and white TV which adds to the setting," writes an online reviewer (Lutz; for a fuller discussion, see Caracciolo, "Narrative Space" 431-432). The absence of color acts as a unifying backdrop to readers' mental imagery, making the narrative space more tangible and therefore easily imaginable: the uniformity of the landscape eases readers into the storyworld, creating a strong sense of physical presence. To this end, McCarthy leverages the connection between color and affective qualities: through the denial of color, the dramatic contrast between the pre- and the postapocalyptic world is affectively realized in the novel (and, potentially, in readers' imagination) even before the narrative registers-by way of direct representation - the consequences of the disaster. Grayness becomes a visual stand-in for the dyadic structure of the storyworld, a layer superimposed on familiar realities and signaling - through the negation and subtraction of color-the inescapability of disaster.

Even beyond this pall of grayness, the spaces explored by the characters are remarkably bare and empty. Consider, for instance, a passage in which the man enters a house in search of food or usable tools:

He went through the house room by room. He found nothing. A spoon in a bedside drawer. He put that in his pocket. He thought there might be some clothes in a closet or some bedding but there wasnt [sic]. He went back out and crossed to the garage. He sorted through tools. Rakes. A shovel. Jars of nails and bolts on a shelf. A boxcutter. He held it to the light and looked at the rusty blade and put it back. Then he picked it up again. He took a screwdriver from a coffee can and opened the handle. Inside were four new blades. He took out the old blade and laid it on the shelf and put in one of the new ones and screwed the handle back together and retracted the blade and put the cutter in his pocket. 
Then he picked up the screwdriver and put that in his pocket as well. He walked back out to the barn. (119-120)

There is very little here in the way of concrete spatial references that may help readers imagine the house and the garage. Space is only seen as a physical container for objects that may ensure the protagonists' survival, and even these objects are captured through a list-like enumeration that emphasizes their scarcity ("Rakes. A shovel," etc.). Yet, in the domain of readers' mental imagery, less is more: the rarer and more isolated these objects appear, the easier it becomes to visualize them against the background of the ghostly house and garage. This phenomenon has something in common with so-called "verbal overshadowing" (see Schooler and Engstler-Schooler), a well-known psychological interference between visual memory and verbalization: several studies found that verbally describing a new face impairs the subsequent visual recognition of that face. While visual memory and mental imagery are not the same thing, it is at least conceivable that McCarthy's sparse style of spatial description encourages the production of mental imagery. The man's movements may also contribute to this effect: they lend a dynamic quality to readers' mental imagery, as if following him through this environment compensated for the lack of explicit spatial information. This idea is consistent with Kuzmičová's argument about the role of object-directed movements in creating an illusion of "presence" in storyworlds. At the same time, the man's movements feel automatic and almost gratuitous, and the house even more empty and lifeless because of that: paradoxically, the description denies spatial detail and foregrounds absence ("He found nothing") even as it is likely to evoke vivid mental imagery in readers.

When, a few pages later, the protagonists discover a bunker miraculously replete with "crate upon crate of canned goods," the man remarks "I found everything. Everything" (138). But this temporary abundance only reminds the man of the extent of the loss, and how it cannot be communicated to the child, who was born after the disaster: "he could not construct for the child's pleasure the world he'd lost without constructing the loss as well and he thought perhaps the child had known this 
better than he" (154). Material objects encode the dyadic structure of the storyworld, the catastrophic rupture between the time before and the time after the disaster.

Negation is not only active in the visual and spatial domain, however, because absence defines this world at a deep, existential level: the narrator compares it to a "crushing black vacuum" (130) that swallows up the material comforts of the pre-world as well as emotions and-especially-hopes of long-term survival and flourishing. Language itself is impacted: the world, we read, was "shrinking down about a raw core of parsible entities. The names of things slowly following those things into oblivion. Colors. The names of birds. Things to eat. ... How much was gone already? The sacred idiom shorn of its referents" (88-89). As the world becomes sparser, the richness of language is pared down to a "raw core" of words. McCarthy's own style mirrors this depletion, with short sentences and monolithic words competing with the barrenness of the landscape: a degree of formal abstraction (reminiscent of the geometrical structure of the Kanizsa triangle) serves to increase the vividness of the storyworld. The novel's thematic and stylistic strategies thus work in tandem with the negation of color and spatial detail that defines readers' experience of this landscape.

\section{Undercutting Narrative Continuity: Zone One}

Colson Whitehead's Zone One reappraises a genre-zombie fiction-that has been a staple of popular culture since George Romero's Night of the Living Dead. Many of the elements that define zombie narratives are present, but they are packaged in an unapologetically challenging text, one in which Whitehead's elaborate prose eclipses the plot-driven thrills of genre fiction. The premise is that a deadly virus has turned millions of Americans into zombie-like "skels" (as the novel calls them), with the exception of a handful of individuals who have been lucky enough to dodge the contagion. Sometime after the outbreak, the survivors begin to reorganize; marines and later paramilitary troops-among them the protagonist, Mark Spitz-sweep through the southern tip of Manhattan in order to clear its buildings of the remaining skels. A few blocks to the north, a concrete wall keeps 
other skels from entering the sanitized perimeter of what is known as "Zone One" -the first step in the reconstruction of a semblance of civil society.

While set for the most part in the post-world, the novel teems with flashbacks to earlier time frames, either the pre-world of Mark's childhood or his perilous journey to New York City in the immediate aftermath of the virus outbreak. These flashbacks are quite unlike McCarthy's sentence-length dream sequences: they extend over several pages, and they tend to be left unannounced and unmarked. A striking example can be found in the opening of the novel, which-far from providing us with the basic coordinates of this postapocalyptic world-veers towards an episode of Mark's youth: "He always wanted to live in New York. His Uncle Lloyd lived downtown on Lafayette, and in the long stretches between visits he daydreamed about living in his apartment" (2-3). On a first reading of this opening, there is no way to know that the transition between the two sentences already implies a leap from the post- to the pre-world: the first sentence-of the quotation and of the novel-is anchored to the protagonist's consciousness as he is making his way through an apartment complex in New York City and dispatching the remaining skels; the second sentence reflects Mark's recollection of his childhood impressions of New York. Readers realize that this is a flashback only much later, and retrospectively. This episode is representative of Whitehead's narrative method in Zone One, which favors a free-floating temporality that constantly blurs the dividing line between the pre- and the post-world. In fact, these flashbacks are so frequent, and their signposting so elusive, that readers will have a hard time following the narrative's trajectory. To quote from an online review of the novel, "flashbacks start and end without any warning-sometimes in the middle of a paragraph, or as part of a random observation-and major plot twists are both telegraphed and buried in other random pieces of information" (Anders). The disorienting effect of this strategy is exacerbated by the scarcity of paratextual cues: the three-hundred page novel is divided into three chapters, titled respectively "Friday," "Saturday," and "Sunday," which offer little help as the reader attempts to piece together the plot and the novel's expansive chronology. 
Perhaps the closest literary parallel is Virginia Woolf's "tunnelling" method (see Showalter xxix), which enabled the narrators of novels such as Mrs. Dalloway and To the Lighthouse to weave in and out of the characters' minds, through ad-hoc flashbacks. In Zone One, just as in Woolf's seminal modernist works, these temporal shifts follow-or are at least inspired by-movements internal to the protagonist's consciousness: typically, remembering a salient episode of his (pre- or postapocalyptic) past. But Mark's past, unlike that of Woolf's characters, remains an incomplete patchwork, which is bound to frustrate readers' need for narrative as well as formal closure (a distinctive feature of Woolf's modernist aesthetics; see Caracciolo, "Leaping into Space"). Surely, this resistance is in itself psychologically justified, because it becomes bound up with catastropheinduced trauma, what the survivors of Zone One refer to as "PASD" (Post-Apocalyptic Stress Disorder, a not entirely unironic label). As one of the novel's characters emphasizes in a conversation with Mark (69), the pronunciation of this acronym makes it virtually indistinguishable from the word "past," thus further cementing the link between the character's traumatic memory of the past and the novel's loose temporality: the temporal structure of the novel mirrors the disruption brought about by catastrophe not just in the storyworld's external reality but-more importantly-in the protagonist's understanding of his life.

We have seen that St. John Mandel and McCarthy foreground the temporal rupture brought about by catastrophe through strategies of negation directed at storyworld objects and spaces. Zone One is not devoid of these moments: for instance, in a memorable episode the protagonist finds shelter in an eerily "prim and elegant" farmhouse that evokes the orderliness and material comforts of the preapocalyptic world, not unlike McCarthy's bunker (210). But far more striking in Whitehead's novel is another negative strategy: Zone One consistently negates narrative continuity and closure as Mark, the protagonist, struggles to make sense of his life. Psychologists working in the wake of Jerome Bruner have persuasively argued that narrative is a fundamental tool in the construction of a coherent personal identity. Marya Schechtman, for instance, writes that "we constitute ourselves as persons by forming a narrative self-conception according to which we experience and organize our 
lives.... What this means more specifically is that we experience the present in the context of a larger life-narrative" (162). Catastrophe denies the protagonist precisely the possibility of a coherent, well-ordered life narrative. This denial is registered in the novel not only through the disorienting flashbacks but also, thematically, through the multiplication of "Last Night stories" - the survivors' accounts of where they were and what they were doing on the night in which the disease broke out.

Mark, we are told, has three versions of his Last Night story, which are deployed according to the degree of intimacy he enjoys with his interlocutors: "The Silhouette was for survivors he wasn't going to travel with for long.... He offered the Anecdote, robust and carrying more on its ribs, to those he might hole up with for a night" (138). Finally, the aptly named "Obituary" was "nonetheless heartfelt, glancing off his true self more than once, replete with digressions about his lifelong friendship with Kyle, nostalgia for the old A.C. trips, the unsettling and 'off' atmosphere of that last casino weekend, and a thorough description of the tableau at his house and its aftermath" (139). The Obituary may "glance off" Mark's true self, but it is still unable to bring together the strands of his narrative identity. In the world of Zone One, the centrality of narrative is repeatedly foregrounded, but so is its inevitably loose and fragmented nature: stories function like "interstitial narrative sequences ... in first-person shooters," as the narrator puts it, describing the pre-world job of one of the survivors encountered by Mark (217). Stories punctuate the text, like sudden flashes of narrative meaning, but ultimately fail to mold the protagonist's life into a meaningful whole. Mark remains, as the text foregrounds, a postapocalyptic everyman whose trajectory opposes the assumptions of exceptionality or predestination that characterize many survival narratives: "He was their typical, he was their most, he was their average, receiving hearty thumbs-ups from the gents in the black van parked a discreet distance across the street" (11; italics in the original).

The novel thus plays with the idea of a satisfying, and liberating, narrativization of catastrophe, and impresses this need for narrative meaning-making on the reader; but, at the same time, it denies this possibility through its loose, erratic progression, which challenges readers' expectations of narrative 
closure. This dynamic is similar to how the Kanizsa triangle both creates and undercuts the illusion of a contour-and therefore of geometrical closure. Whitehead's literary method thus translates the workings of the triangle-the imaginative co-existence of a shape and its absence-to the level of narrative coherence. In turn, the falling short of narrative can be seen as a result of what the "skels" (the zombies) embody in Zone One on a symbolic level: they are a collective, nonhuman agent that resists narrative because of its deep-seated unpredictability. We are thus brought back to the question of how narrative can confront the interrelation between human societies and phenomena beyond the human. The novel raises this question by repeatedly suggesting that the skels are "a kind of weather" (221), a comparison that both stresses the haphazardness of their behavior and points to the equation between the zombie apocalypse and the real-world possibility of climate changeinduced catastrophe. When Mark finds himself in a farmhouse about to be overrun by hordes of skels, he pictures "himself underneath the news copter as the folks in more fortunate weather watched from home. He was on the roof, the brown floodwaters pouring around the house" (228). The skels' movements have the unpredictable but ruthless logic of extreme weather. Likewise, at the end of the novel, the skels break through the wall that had secured Zone One; the narrator comments, with an even more explicit association between the skels, which are compared to an "ocean," and climate change: "The ocean had overtaken the streets, as if the news programs' global warming simulations had finally come to pass and the computer-generated swells mounted to drown the great metropolis" (302). The novel's negation of narrative continuity is a literary response to the problem of imagining nonhuman realities: realities that-like the skels or, in the real world, anthropogenic climate change-put pressure on narrative's inherent anthropocentrism.

\section{Conclusion}

The point of departure for this article was the tension-which Herman sees as fundamental to narrative-between stories' capacity to evoke experientially thick mental domains ("storyworlds") and the representation of disruptive events ("world disruption"). Catastrophe is a limit case of world disruption, in that it constitutes a radical, large-scale deviation from a state of affairs seen as normal 
or ordinary. This explains why catastrophe is, at the same time, so productive and so challenging for narrative. On the one hand, due to its inherent tellability catastrophe is likely to generate a profusion of stories, fictional as well as nonfictional. The link between narrative and catastrophe runs deep: some of the oldest written narratives (from the Epic of Gilgamesh to the Genesis and Greek mythology) focus on natural disasters and their consequences. But while in these classical narratives catastrophe is presented as the result of divine intervention in human history, in today's world catastrophic occurrences tend to be conceptualized as the product of a complex causality, crisscrossing human and nonhuman factors. This raises an important challenge for narrative. As a practice geared towards the human scale, storytelling shows a bias for individual protagonists and the spatio-temporal framework of human existence. Plot is keyed to human or human-like intentionality, whereas modern catastrophe (unlike the pre-modern understanding of catastrophe as divine intervention) denies intentionality. Thus, capturing catastrophe puts pressure on the structures of narrative, a challenge that is central to the genre of postapocalyptic fiction. Innovative takes on this genre-such as my case studies in this article-build on culturally circulating postapocalyptic narratives while using them to probe and question the dividing line between human societies and geological or climatological processes. In fact, these more sophisticated narratives are capable of disclosing, in Kate Rigby's words, "the entanglement-material, but potentially also moral-of human and nonhuman actors and factors in the etiology, unfolding, and aftermath of catastrophes that turn out to straddle the dubious nature-culture divide" ("Confronting Catastrophe" 214).

The three novels examined in this article bring to the fore this interrelation by implementing what I have characterized as negative strategies, which exploit basic features of linguistic comprehension as well as mental imagery in order to juxtapose two states of the storyworld: what preceded the catastrophic event, and what came after it. In an effort to convey this temporally dyadic structure, negation is elevated to a formal principle: it underlies the enumeration of objects no longer in existence as well as frequent chapter-length flashbacks to the pre-world (Station Eleven); it inspires 
McCarthy's approach to spatial description in The Road, with its gray landscapes and bare environments; and, lastly, it shapes the protagonist's inability to bring satisfying narrative closure to his life in Zone One. These negative strategies are able to evoke-and impress on readers-a sense of the pre-world's absence, which accounts for the haunting quality of these narratives and their lasting imaginative impact. The temporal scale of catastrophe-its straddling several human generationsas well as its restructuring of familiar spaces are thus compressed into an affective experience that is shared by the protagonists and by readers alike. This emotional effect is heightened by the preworld's proximity with the real world, so that the novels-even when they do not foreground climatological processes-resonate symbolically with contemporary anxieties about climate change. Clearly, the argument offered in this article is only a first step towards understanding the narratological challenges raised by nonhuman phenomena, of which catastrophe and the postapocalyptic genre are a particularly salient manifestation. For now, I hope to have shown convincingly that insight into readers' psychological processing of narrative can help us come to grips with these challenges as well as the formal solutions they prompt.

\section{Works Cited}

Anders, Charlie Jane. "Colson Whitehead's Zone One Shatters Your Post-Apocalyptic Fantasies." http://gizmodo.com/. N.p., 29 Dec. 2011. Web. 26 Apr. 2017.

Berger, James. After the End: Representations of Post-Apocalypse. Minneapolis: University of Minnesota Press, 1999. Print.

Blanchot, Maurice. The Writing of the Disaster. Trans. Ann Smock. Lincoln: University of Nebraska Press, 1986. Print.

Bruner, Jerome. "The Narrative Construction of Reality." Critical Inquiry 18 (1991): 1-21. Print.

Caracciolo, Marco. "Leaping into Space: The Two Aesthetics of To the Lighthouse." Poetics Today 31.2 (2010): 251-284. Print.

---. “Narrative Space and Readers' Responses to Stories: A Phenomenological Account." Style 47.4 (2013): 425-444. Print. 
---. “Object-Oriented Plotting and Non-Human Realities in DeLillo's Underworld and Iñárritu's Babel." Ecocriticism and Narrative Theory: Essays at a Critical Confluence. Ed. Erin James and Eric Morel. Columbus: Ohio State University Press, under review. Print.

Doležel, Lubomír. Heterocosmica: Fiction and Possible Worlds. Baltimore: Johns Hopkins University Press, 1998. Print.

Fludernik, Monika. Towards a "Natural" Narratology. London: Routledge, 1996. Print.

Gilbert, Daniel T. “How Mental Systems Believe.” American Psychologist 46.2 (1991): 107-119. Print.

Grusin, Richard, ed. The Nonhuman Turn. Minneapolis: University of Minnesota Press, 2015. Print.

Herman, David. Basic Elements of Narrative. Chichester: Wiley-Blackwell, 2009. Print.

---. "Narratology beyond the Human." DIEGESIS 3.2 (2014): n. pag. www.diegesis.uni-wuppertal.de. Web. 24 Feb. 2015

Horn, Laurence R. A Natural History of Negation. Stanford: CSLI Publications, 1989. Print.

James, Erin. The Storyworld Accord: Econarratology and Postcolonial Narratives. Lincoln: University of Nebraska Press, 2015. Print.

Kanizsa, Gaetano. "Margini quasi-percettivi in campi con stimolazione omogenea." Rivista di Psicologia 49.1 (1955): 7-30. Print.

Kohlmann, Benjamin. "What Is It Like to Be a Rat? Early Cold War Glimpses of the Post-Human." Textual Practice 28.4 (2014): 655-675. Print.

Kukkonen, Karin, and Marco Caracciolo. "Introduction: What Is the 'Second Generation'?" Style 48.3 (2014): 261-274. Print.

Kuzmičová, Anežka. "Presence in the Reading of Literary Narrative: A Case for Motor Enactment." Semiotica 189.1/4 (2012): 23-48. Print.

Lutz, Sonja L. "The Road." Amazon.com Customer Reviews 13 May 2007. Web. 16 Feb. 2012.

Mandel, Emily St. John. Station Eleven. Vintage, 2014. Print.

McCarthy, Cormac. The Road. New York: Knopf, 2006. Print. 
Richardson, Brian. "Denarration in Fiction: Erasing the Story in Beckett and Others." Narrative 9.2 (2001): 168-175. Print.

Rigby, Kate. "Confronting Catastrophe: Ecocriticism in a Warming World." The Cambridge Companion to Literature and the Environment. Ed. Louise Westling. Cambridge: Cambridge University Press, 2013. 212-225. Print.

---. Dancing with Disaster: Environmental Histories, Narratives, and Ethics. Charlottesville: University of Virginia Press, 2015. Print.

Sartre, Jean-Paul. The Psychology of Imagination. New York: Philosophical Library, 1948. Print.

Scarry, Elaine. Dreaming by the Book. Princeton: Princeton University Press, 2001. Print.

Schechtman, Marya. "Stories, Lives, and Basic Survival: A Refinement and Defense of the Narrative View." Narrative and Understanding Persons. Ed. Daniel D. Hutto. Cambridge: Cambridge University Press, 2007. 155-178. Print.

Schooler, Jonathan W., and Tonya Y. Engstler-Schooler. "Verbal Overshadowing of Visual Memories: Some Things Are Better Left Unsaid." Cognitive Psychology 22 (1990): 36-71. Print.

Showalter, Elaine. "Introduction." Mrs. Dalloway. London: Penguin, 1992. xi-xliix. Print.

Thompson, Evan. "Look Again: Phenomenology and Mental Imagery." Phenomenology and the Cognitive Sciences 6 (2007): 137-170. Print.

Whitehead, Colson. Zone One. New York: Doubleday, 2011. Print. 